\title{
REMAKING THE CHINESE EMPIRE
}





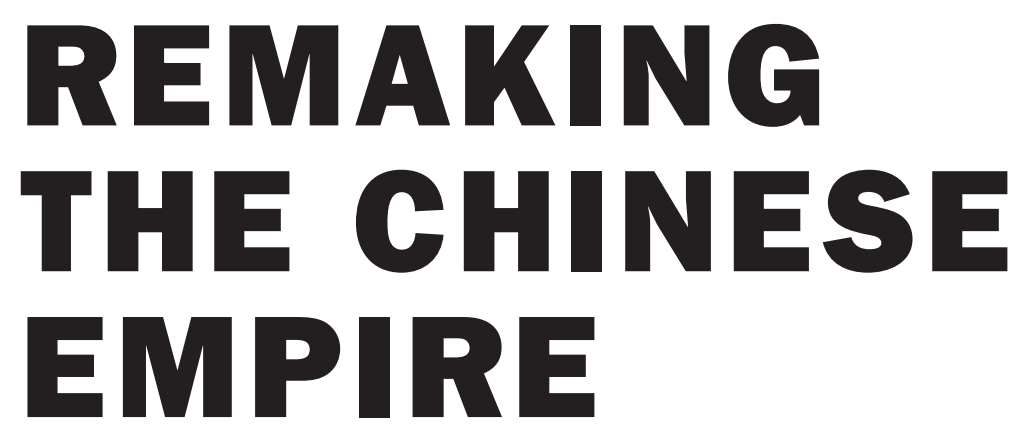

Manchu-Korean Relations,

1616-1911

Yuanchong Wang 


\section{Copyright @ 2018 by Cornell University}

All rights reserved. Except for brief quotations in a review, this book, or parts thereof, must not be reproduced in any form without permission in writing from the publisher. For information, address Cornell University Press, Sage House, 512 East State Street, Ithaca, New York 14850. Visit our website at cornellpress.cornell.edu.

First published 2018 by Cornell University Press

Printed in the United States of America

Library of Congress Cataloging-in-Publication Data

Names: Wang, Yuanchong, 1979- author.

Title: Remaking the Chinese empire : Manchu-Korean relations, 1616-1911 / Yuanchong Wang.

Description: Ithaca : Cornell University Press, 2018. | Includes bibliographical references and index.

Identifiers: LCCN 2018023443 (print) | LCCN 2018029151 (ebook) | ISBN 9781501730511 (pdf) | ISBN 9781501730528 (epub/mobi) | ISBN 9781501730504 | ISBN 9781501730504 (cloth ; alk. paper)

Subjects: LCSH: China—Foreign relations—Korea. | KoreaForeign relations-China. | China-Foreign relations-1644-1912. Classification: LCC DS740.5.K6 (ebook) | LCC DS740.5.K6 W335 2018 (print) | DDC 327.51051909/03-dc23

LC record available at https://lccn.loc.gov/2018023443

Cover illustration: Qing imperial envoys crossing the Yalu River to Chosŏn in the 1720s. In Fengshi tu, preserved in the Ethnic Library of China, Beijing. 